\title{
Diet Content of Non-Saturated Fatty Acids is Related to Lower Plasma Adiponectin in Patients with Metabolic Syndrome
}

\section{Juan Antonio Suárez-Cuenca}

Centro Médico Nacional 20 de Noviembre: Centro Medico Nacional 20 de Noviembre

Diana Elisa Díaz-Jiménez

IMSS: Instituto Mexicano del Seguro Social

Juan Antonio Pineda-Juárez ( $\nabla$ pinedaj.ja@gmail.com )

Centro Médico Nacional 20 de Noviembre: Centro Medico Nacional 20 de Noviembre

Alondra Gissel Mendoza-Mota

Centro Médico Nacional 20 de Noviembre: Centro Medico Nacional 20 de Noviembre

Ofelia Dinora Valencia-Aldana

Centro Médico Nacional 20 de Noviembre: Centro Medico Nacional 20 de Noviembre

Said Núñez-Angeles

Centro Médico Nacional 20 de Noviembre: Centro Medico Nacional 20 de Noviembre

\section{Eduardo Vera-Gómez}

Centro Médico Nacional 20 de Noviembre: Centro Medico Nacional 20 de Noviembre

Alejandro Hernández-Patricio

Centro Médico Nacional 20 de Noviembre: Centro Medico Nacional 20 de Noviembre Mónica Escamilla-Tilch

Centro Médico Nacional 20 de Noviembre: Centro Medico Nacional 20 de Noviembre

Pavel Loeza-Magaña

Centro Médico Nacional 20 de Noviembre: Centro Medico Nacional 20 de Noviembre Jorge Antonio Lara-Vargas

Centro Médico Nacional 20 de Noviembre: Centro Medico Nacional 20 de Noviembre

Rebeca Pérez-Cabeza de Vaca

Centro Médico Nacional 20 de Noviembre: Centro Medico Nacional 20 de Noviembre José Rodolfo Arteaga-Martínez

Centro Médico Nacional 20 de Noviembre: Centro Medico Nacional 20 de Noviembre Ángel Alfonso Garduño-Pérez

Centro Médico Nacional 20 de Noviembre: Centro Medico Nacional 20 de Noviembre

\section{Beatriz Barranco-Fragoso}

Centro Médico Nacional 20 de Noviembre: Centro Medico Nacional 20 de Noviembre Jesús Montoya-Ramírez 
Centro Médico Nacional 20 de Noviembre: Centro Medico Nacional 20 de Noviembre María Angélica Díaz-Aranda

Centro Médico Nacional 20 de Noviembre: Centro Medico Nacional 20 de Noviembre Roberto Carlos Chaparro-Hernández

Centro Médico Nacional 20 de Noviembre: Centro Medico Nacional 20 de Noviembre Alberto Melchor-López

Centro Médico Nacional 20 de Noviembre: Centro Medico Nacional 20 de Noviembre

\section{Silvia García}

Centro Médico Nacional 20 de Noviembre: Centro Medico Nacional 20 de Noviembre José Gutiérrez-Salinas

Centro Médico Nacional 20 de Noviembre: Centro Medico Nacional 20 de Noviembre Paul Mondragón-Terán

Centro Médico Nacional 20 de Noviembre: Centro Medico Nacional 20 de Noviembre

\section{Research}

Keywords: adiponectin, metabolic syndrome, diet, fatty acids.

Posted Date: July 27th, 2021

DOI: https://doi.org/10.21203/rs.3.rs-713993/v1

License: (a) (i) This work is licensed under a Creative Commons Attribution 4.0 International License. Read Full License 


\section{Abstract}

Introduction. The metabolic syndrome (MS) has been related to the unbalance between pro- and antiinflammatory cytokines; where adiponectin, an anti-inflammatory adipokine, is considered to play a key metabolic role. The consumption of certain micronutrients has been claimed to modify pro- and antiinflammatory cytokines.

Aim. To explore whether dietary micronutrients are related with plasma adiponectin in patients with MS.

Methods. Cross-sectional analysis. Quartiles of dietary bioactive compounds were compared according to values of plasma adiponectin. Interquartile variation (IQV) and correlation analyses were performed.

Results. There was a significant IQV of dietary unsaturated fatty acids (between $-50 \%$ to $-66 \%$ of change, p25 vs p75, p <0.05), particularly for trans-fatty acids, poly-unsaturated fatty acids, mono-unsaturated fatty acids and $w-6$ fatty acids, in relation to plasma adiponectin; as well as a negative correlation (rho= $-0.53,-0.37,-0.29$ and -0.34 , respectively; $p<0.05)$.

Conclusion. Dietary amounts of unsaturated fatty acids inversely related to plasma adiponectin in patients with MS.

\section{Introduction}

The metabolic syndrome (MS) comprises a set of widely distributed risk factors favoring the development of cardiovascular diseases and type 2 Diabetes Mellitus (DM2) [1-4].

Pathophysiological mechanisms underlying MS have been related to the unbalance between pro- and anti-inflammatory cytokines; where adiponectin, an anti-inflammatory adipokine, is considered to play a key role due to different effects like: 1 ) the induction of other anti-inflammatory cytokines like IL-10 and interleukin 1 receptor antagonist (IL-1RA) in human monocytes, monocyte-derived dendritic cells and macrophages, 2) the regulatory effect on insulin sensitivity, and 3) the anti-atherogenic effect [5-7].

The consumption of pro-inflammatory diets and hyperglycemia have been associated with higher prevalence of hypertension and obesity, suggesting that dietary habits affect metabolic profiles considered of higher risk [6-8].

There is an increasing interest in the study of dietary bioactive compounds with ability to modify plasma cytokines, which has been evidenced through out several longitudinal studies. For example, the consumption of food from animal source has been observed to decrease plasma adiponectin, whereas the intake of vegetable source foods, enriched with fiber and $\omega-3$ fatty acids, may increase plasma adiponectin [5-7]. Likewise, the consumption of high fiber, complex carbohydrates-enriched diet has been reported to increase plasma adiponectin in overweight and obese subjects [9], while low fiber, fat-enriched diet reducted plasma adiponectin in patients with DM2 [10]. Nevertheless, whether other food properties modify adiponectin is less clear and sometimes controversial. Hypocaloric diets have been reported to 
increase plasma adiponectin [11], while other studies have failed to achieve a significant effect of hypocaloric diets on adiponectin [12-14].

Therefore, the present study was designed to explore whether different dietary compounds modify plasma adiponectin in a higher risk population like subjects with MS.

\section{Materials And Methods}

\section{Study Design}

Observational, analytical cross-sectional study.

\section{Setting}

This study was performed at Endocrinology and Bariatric Surgery Departments, as well as Laboratory of Experimental Metabolism and Clinical Research Department, from Centro Médico Nacional "20 de Noviembre", ISSSTE at Mexico City, between 2017 and 2019.

\section{Study population}

Patients older than 18 years old, diagnosed with MS as defined by NCEP/ATP III, meeting at least three of the following components: 1) waist circumference of more than $102 \mathrm{~cm}$ in men or more that $88 \mathrm{~cm}$ in women, 2) fasting triglyceride level of $150 \mathrm{mg} / \mathrm{dL}$ or higher, 3) $\mathrm{HDL}$ cholesterol $\leq 40 \mathrm{mg} / \mathrm{dL}$ for men or 50 $\mathrm{mg} / \mathrm{dL}$ for women, 4) systolic/diastolic blood pressure $\geq 130 / 85 \mathrm{mmHg}$ or receiving drug treatment, and 5) fasting plasma glucose $\geq 100 \mathrm{mg} / \mathrm{dL}$ [2]. Patients were excluded if presence of chronic renal failure, hepatic disease, decompensated heart failure, as well as those patients participating in other protocols involving physical rehabilitation or nutritional programs.

For sample size calculation, we estimated the effect of food content on adiponectin plasma concentration, according to previous reports [7], considering $95 \% \mathrm{Cl}$ alpha $=0.05$, our sample size was $\mathrm{n}=$ 95 , which rendered a beta power of $>0.8$. The study protocol complied with the Declaration of Helsinki and was approved by the Local Ethics Committee. Informed consent was obtained from all patients for study inclusion.

\section{MEASUREMENTS}

\section{Anthropometry}

Clinical-demographic data were obtained through individual interviews performed by experienced researchers. Anthropometric variables (weight, height, BMl, arm and waist circumferences) were obtained by clinical nutrition specialists, according to standard methods [15].

\section{Dietetic habits}


A 24-hour recalls were used to register habitual type of diet, with emphasis in their food schedules and size portions that patients consumed a day before the interview. In case that food consumption on the day before did not reflect the usual diet, patients were asked to describe a habitual day. NASCO® food replicas kit was used to help patients in order to describe the size portions more accurately. All 24-hour recalls were analyzed with the Food Processor ${ }^{\circledR}$ program v.7, allowing estimating the amount of energy (kilocalories), macro- and micro-nutrients. All measurements were performed by 2 previously experienced nutritionists.

\section{Adiponectin determination}

All blood samples were obtained after 8 hours fasting, by antecubital venopuncture. Then, blood was immediately centrifuged $5000 \mathrm{rpm}$ for $5 \mathrm{~min}$, at room temperature and plasma was recovered. Plasma adiponectin was determined by immunomagnetic multiplexing assay (Milliplex Map Human Adiponectin Magnetic Bead Panel Thermo Fischer Scientific, USA), and readings were performed in a MAGPIX System 40-072-EM (Millipore, Austin, Texas, USA). The measurements were processed according to provider specifications.

\section{Statistical analysis}

Normality data analyses were performed with Shapiro-Wilks test. All continuous variables were expressed as mean $\pm \mathrm{SD}$ or median and InterQuartile Range (IQR, $\left.P_{25}, P_{75}\right)$, as appropriate; qualitative data were shown as $\mathrm{n}(\%)$. For inferential analyses, one-tailed, non-paired U-Mann Whitney or T-test were used as appropriate; likewise, Spearman test was used to analyze relation between quantitative data. All statistics tests were performed using software PRISM (v. 6.0) and SPSS (v. 20). Statistical significance was considered if $p \leq 0.05$.

\section{Results}

The study population was constituted by 95 patients with metabolic syndrome, aged 58 years-old, $78.7 \%$ female, with higher prevalence of insulin resistance, dyslipidemia and obesity. Likewise, anthropometric and biochemical parameters indicate cardiometabolic risk (Tables 1 and 2), despite general intake of macronutriments was normal (Table 3). 
Table 1

Clinical-Demographic Characteristics $(\mathrm{n}=95)$

$\begin{array}{ll}\text { Age (years-old) } & 58.5 \pm 9.9 \\ \text { Male ( } \mathrm{n}[\%]) & 20.0(21.3)\end{array}$

\section{Co-morbidities}

Type 2 Diabetes Mellitus (n [\%])

$76.0(80.9)$

Dyslipidemia (n [\%])

$58.0(61.7)$

Obesity (n [\%])

$47.0(50)$

HAS (n [\%])

$59(62)$

\section{Biochemical Data}

Plasma Glucose (mg/dL)

106.0 (93.5 to 126.0 )

Total Cholesterol total $(\mathrm{mg} / \mathrm{dL})$

142.9 (100.0 to 176.0$)$

$\mathrm{c}-\mathrm{HDL}(\mathrm{mg} / \mathrm{dL})$

$45.9 \pm 14.7$

$\mathrm{c}-\mathrm{LDL}(\mathrm{mg} / \mathrm{dL})$

92.4 (62.7 to 120.3$)$

Triglycerides $(\mathrm{mg} / \mathrm{dL})$

$134.3 \pm 47.1$

Adiponectin $(\mathrm{pg} / \mathrm{dL})$

5.44 (2.28 to 12.68$)$

Quantitative data are resumed as mean \pm SD or p50 (p25 to p75) as appropriate; while qualitative data are described as $\mathrm{n}(\%)$. Abbreviatures: c-HDL: high-density cholesterol; c-LDL, low-density cholesterol.

Table 2

Anthropometric Characteristics

\section{Weight (Kg)}

$\operatorname{BMI}\left(\mathrm{Kg} / \mathrm{m}^{2}\right)$

Brachial Circumference $(\mathrm{cm})$

Wrist Circumference $(\mathrm{cm})$

Hip Circumference $(\mathrm{cm})$
$78.3 \pm 17.1$

28.9 (26.3 to 32.6$)$

32.5 (29.5 to 35.4$)$

99.5 (91.2 to 106.0$)$

102.0 (96.3 to 111.8$)$

Quantitative data are resumed as mean \pm SD or p50 (p25 to p75) as appropriate; while qualitative data are described as $\mathrm{n}(\%)$. Abbreviatures: BMI, Body Mass Index. 
Table 3

Macronutriments Consumption

\section{Energy (Kcal)}

Proteins (g)

Carbohydrates (g)

Lipids (g)

\section{5 (1083.7 to 1874.1$)$}

$71.4 \pm 27.5$

185.0 (116.5 to 252.8$)$

$51.2 \pm 30.5$

Quantitative data are resumed as mean \pm SD or p50 (p25 to p75) as appropriate; while qualitative data are described as n (\%). Abbreviatures: BMI, Body Mass Index.

The study population was divided by quartiles according to the amount of nutriment composition in the diet. Then, value of plasma adiponectin was distributed between the quertiles of nutriments. A significant progressive reduction of adiponectin accross the increasing quartiles of nutriments was observed for trans- fatty acids, PUFAs, mono-unsaturated fatty acids and $\omega-6$ fatty acids (Table 4 ). 
Table 4

Dietary Micronutrients and Plasma Adiponectin

\begin{tabular}{|c|c|c|c|c|c|c|c|}
\hline & \multicolumn{5}{|c|}{ Plasma Adiponectin (pg/dL) according to Micronutrients } & \multicolumn{2}{|c|}{$\begin{array}{l}\% \text { Change } P 25 \\
\text { vs P75 }\end{array}$} \\
\hline & Q1 & Q2 & Q3 & Q4 & $\begin{array}{l}\mathrm{p}- \\
\text { value }\end{array}$ & & $\begin{array}{l}p- \\
\text { value }\end{array}$ \\
\hline Trans- FA (g) & $\begin{array}{l}7.2(4.4 \text { to } \\
10.5)\end{array}$ & $\begin{array}{l}4.5(2.9 \text { to } \\
7.4)\end{array}$ & $\begin{array}{l}4.5(2.3 \text { to } \\
7.8)\end{array}$ & $\begin{array}{l}2.4(1.9 \text { to } \\
4.8)\end{array}$ & 0.01 & -66.62 & 0.01 \\
\hline PUFA (g) & $\begin{array}{l}6.2(2.2 \text { to } \\
10.9)\end{array}$ & $\begin{array}{l}7.1(4.0 \text { to } \\
11.9)\end{array}$ & $\begin{array}{l}3.0(2.3 \text { to } \\
5.8)\end{array}$ & $\begin{array}{l}2.6(2.1 \text { to } \\
4.5)\end{array}$ & 0.004 & -57.95 & 0.01 \\
\hline $\begin{array}{l}\text { Mono- } \\
\text { unsaturated FA } \\
\text { (g) }\end{array}$ & $\begin{array}{l}5.6(2.2 \text { to } \\
9.9)\end{array}$ & $\begin{array}{l}5.6 \text { (3.0 to } \\
9.8 \text { ) }\end{array}$ & $\begin{array}{l}3.6(2.3 \text { to } \\
6.1)\end{array}$ & $\begin{array}{l}2.6(1.6 \text { to } \\
4.9)\end{array}$ & 0.06 & -53.75 & 0.03 \\
\hline$\omega-6$ FA (g) & $\begin{array}{l}6.7(2.3 \text { to } \\
9.9)\end{array}$ & $\begin{array}{l}6.2(3.0 \text { to } \\
10.6)\end{array}$ & $\begin{array}{l}4.0(2.2 \text { to } \\
6.2)\end{array}$ & $\begin{array}{l}3.3(2.3 \text { to } \\
4.5)\end{array}$ & 0.05 & -50.97 & 0.04 \\
\hline Potassium (mg) & $\begin{array}{l}3.0(2.1 \text { to } \\
11.9)\end{array}$ & $\begin{array}{l}5.4 \text { (3.0 to } \\
9.5 \text { ) }\end{array}$ & $\begin{array}{l}4.5(2.6 \text { to } \\
7.2\end{array}$ & $\begin{array}{l}5.4(2.2 \text { to } \\
6.7)\end{array}$ & 0.49 & 77.74 & 0.88 \\
\hline Calcium (mg) & $\begin{array}{l}6.5(3.8 \text { to } \\
12.8)\end{array}$ & $\begin{array}{l}4.5(2.4- \\
6.9)\end{array}$ & $\begin{array}{l}3.8(2.2 \text { to } \\
5.7)\end{array}$ & $\begin{array}{l}3.3(2.3 \text { to } \\
7.7)\end{array}$ & 0.14 & -49.15 & 0.05 \\
\hline Vitamin B6 (mg) & $\begin{array}{l}5.8 \text { (3.9 to } \\
6.9)\end{array}$ & $\begin{array}{l}4.5 \text { (1.9 to } \\
9.0)\end{array}$ & $\begin{array}{l}4.4(2.2 \text { to } \\
8.8)\end{array}$ & $\begin{array}{l}3.0(2.4 \text { to } \\
4.9)\end{array}$ & 0.23 & -47.77 & 0.04 \\
\hline Vitamin B2 (mg) & $\begin{array}{l}6.3 \text { (3.9 to } \\
9.4)\end{array}$ & $\begin{array}{l}4.5(2.3 \text { to } \\
8.3)\end{array}$ & $\begin{array}{l}4.5 \text { (1.9 to } \\
7.7)\end{array}$ & $\begin{array}{l}3.3 \text { (2.4 to } \\
7.0)\end{array}$ & 0.37 & -47.61 & 0.07 \\
\hline Cholesterol (mg) & $\begin{array}{l}5.2(4.0 \text { to } \\
9.9)\end{array}$ & $\begin{array}{l}5.4(2.2 \text { to } \\
7.2)\end{array}$ & $\begin{array}{l}4.5(2.3 \text { to } \\
8.3)\end{array}$ & $\begin{array}{l}2.9(2.3 \text { to } \\
6.5)\end{array}$ & 0.45 & -42.33 & 0.08 \\
\hline Vitamin E (UI) & $\begin{array}{l}7.0(2.5 \text { to } \\
12.0)\end{array}$ & $\begin{array}{l}5.4(2.4 \text { to } \\
10.6)\end{array}$ & $\begin{array}{l}4.1(2.3 \text { to } \\
7.0)\end{array}$ & $\begin{array}{l}5(2.3 \text { to } \\
5.4)\end{array}$ & 0.25 & -41.46 & 0.06 \\
\hline Vitamin C (mg) & $\begin{array}{l}4.0(1.5 \text { to } \\
7.1)\end{array}$ & $\begin{array}{l}3.8(2.6 \text { to } \\
5.4)\end{array}$ & $\begin{array}{l}3.8(2.6 \text { to } \\
5.4)\end{array}$ & $\begin{array}{l}5.8(2.6 \text { to } \\
9.1)\end{array}$ & 0.82 & 40.59 & 0.88 \\
\hline Vitamin B1 (mg) & $\begin{array}{l}5.6 \text { (3.7 to } \\
9.9)\end{array}$ & $\begin{array}{l}3.8 \text { (2.0 to } \\
6.5)\end{array}$ & $\begin{array}{l}4.5(2.0 \text { to } \\
8.9)\end{array}$ & $\begin{array}{l}3.5(2.2 \text { to } \\
6.5)\end{array}$ & 0.37 & -36.96 & 0.04 \\
\hline Sodium (mg) & $\begin{array}{l}6.2(2.7 \text { to } \\
9.9)\end{array}$ & $\begin{array}{l}3.1(2.1 \text { to } \\
5.4)\end{array}$ & $\begin{array}{l}4.3(2.4 \text { to } \\
8.1)\end{array}$ & $\begin{array}{l}4.1 \text { (2.8 to } \\
8.0)\end{array}$ & 0.1 & -33.6 & 0.41 \\
\hline $\begin{array}{l}\text { Carbohydrates } \\
\text { (g) }\end{array}$ & $\begin{array}{l}5.2(2.4 \text { to } \\
9.9)\end{array}$ & $\begin{array}{l}4.5(2.3 \text { to } \\
6.6)\end{array}$ & $\begin{array}{l}4.1(2.1 \text { to } \\
7.1)\end{array}$ & $\begin{array}{l}3.7(2.3 \text { to } \\
8.5)\end{array}$ & 0.9 & -28.6 & 0.58 \\
\hline Vitamin B3 (mg) & $\begin{array}{l}5.4(2.3 \text { to } \\
6.8)\end{array}$ & $\begin{array}{l}5.0 \text { (3.1 to } \\
1.7)\end{array}$ & $\begin{array}{l}2.5(2.1 \text { to } \\
8.9)\end{array}$ & $\begin{array}{l}4(2.5 \text { to } \\
5.8)\end{array}$ & 0.49 & -26.65 & 0.4 \\
\hline$\omega-3$ FA (g) & $\begin{array}{l}4.5(1.9 \text { to } \\
6.8)\end{array}$ & $\begin{array}{l}5.4(2.3 \text { to } \\
9.4)\end{array}$ & $\begin{array}{l}5.4(2.9 \text { to } \\
7.5)\end{array}$ & $\begin{array}{l}3.9(2.5 \text { to } \\
6.1)\end{array}$ & 0.57 & -14.61 & 0.84 \\
\hline
\end{tabular}




\begin{tabular}{|c|c|c|c|c|c|c|c|}
\hline \multirow[b]{2}{*}{ Selenium (mcg) } & \multicolumn{5}{|c|}{ Plasma Adiponectin (pg/dL) according to Micronutrients } & \multicolumn{2}{|c|}{$\begin{array}{l}\% \text { Change } P 25 \\
\text { vs P75 }\end{array}$} \\
\hline & $\begin{array}{l}5.0(2.2 \text { to } \\
10.2)\end{array}$ & $\begin{array}{l}5.4(3.4 \text { to } \\
8.3)\end{array}$ & $\begin{array}{l}3.8 \text { (2.2 to } \\
8.9)\end{array}$ & $\begin{array}{l}4.5(2.4 \text { to } \\
5.6)\end{array}$ & 0.55 & -10.1 & 0.34 \\
\hline Folate (mcg) & $\begin{array}{l}4.3(2.3 \text { to } \\
9.1)\end{array}$ & $\begin{array}{l}3.9(2.9 \text { to } \\
6.4)\end{array}$ & $\begin{array}{l}5.8(1.7 \text { to } \\
9.6)\end{array}$ & $\begin{array}{l}3.8 \text { ( } 2.3 \text { to } \\
6.2)\end{array}$ & 0.57 & -6.86 & 0.57 \\
\hline Satured FA (g) & $\begin{array}{l}4.7(2.1 \text { to } \\
9.4)\end{array}$ & $\begin{array}{l}4.7(2.1 \text { to } \\
9.4)\end{array}$ & $\begin{array}{l}3.1 \text { (2.3 to } \\
6.1)\end{array}$ & $\begin{array}{l}4.9(2.1 \text { to } \\
12.0)\end{array}$ & 0.45 & 3.16 & 0.99 \\
\hline Vitamin D (UI) & $\begin{array}{l}3.8(2.2 \text { to } \\
11.5)\end{array}$ & $\begin{array}{l}6.3(3.9 \text { to } \\
7.5)\end{array}$ & $\begin{array}{l}2.3(1.7 \text { to } \\
4.6)\end{array}$ & $\begin{array}{l}5.4(2.8 \text { to } \\
6.0)\end{array}$ & 0.16 & 0 & 0.81 \\
\hline \multicolumn{8}{|c|}{$\begin{array}{l}\text { Adiponectin was distributed according to quartiles of dietary micronutrients ( } \mathrm{Q} 1 \text { refers to }<\mathrm{p} 25 ; \mathrm{Q} 2 \\
\text { refers to } \mathrm{p} 25-50 ; \mathrm{Q} 3 \text { refers to } \mathrm{p} 50-\mathrm{p} 75 \text { and } \mathrm{Q} 4 \text { refers to }>\mathrm{p} 75 \text { ). Interquartile viariance was compared b) } \\
\text { Kruskall-Wallis test. Then, the magnitude of change was estimated by U-Mann-Whithney test. } \\
\text { Abbreviatures: FA, Fatty Acids; PUFA, Poly-unsaturated fatty acids. }\end{array}$} \\
\hline
\end{tabular}

The highest correlations between nutriments amounts and plasma adiponectin are shown in Fig. 1, highlighting the moderate negative correlation between trans- fatty acids $(-0.53, \mathrm{Cl} 95 \%-0.70$ to $-0.31, \mathrm{p}=$ $0.0001)$; PUFA $(-0.37, \mathrm{Cl} 95 \%-0.57$ to $-0.12, \mathrm{p}=0.0019) ; \omega-6$ fatty acids $(-0.33, \mathrm{Cl} 95 \%-0.54$ to $0.08, \mathrm{p}=$ $0.0043)$ and mono-unsaturated fatty acids $(-0.29, \mathrm{Cl} 95 \%-0.51$ to $0.03, \mathrm{p}=0.012)$ with plasma adiponectin.

\section{Discussion}

Our main finding was the inverse relation adiponectin with diet amount of unsaturated fatty acids, particularly trans-fatty acids, poly-unsaturated fatty acids, mono-unsaturated fatty acids and $\omega-6$ fatty acids.

Our results are similar to observations reported by Esposito et al, where consumption of a high fat, low fiber diet for 1 week induced a reduction of plasma adiponectin, either in healthy individuals and patients with DM2 [10].

In the other hand, Peake et al. showed that consumption of a saturated fat-rich breakfast for approximately 1 week did not significantly modified plasma adiponectin in healthy individuals or patients with DM2; while Paniagua et al. did not observed difference in mRNA adiponectin between consumption of saturated- $v s$ unsaturated fatty acid-rich breakfast for 3 days in healthy individuals with metabolic risk factors. Such controversies with our findings may be explained by variations in the study design, methods to measure adiponectin, the type of fatty acids and time of consumption [16,17], suggesting that the effect of unsaturated fatty acids on adiponectin is specific and may depand on the time of consumption, for at least 1 week.

Our findings are in line with some mechanisms proposed to explain why specific unsaturated fatty acids, calcium and piridoxin may decrease adiponectin. PUFA may modulate enzymes responsible for 
adiponectin expression through AMPK pathway in the liver and adipocytes; or peroxidation particularly of linoleic acid produces hydroxyalkenal 4-hydroxynonenal derivate, which may reduce adiponectin gene $[18,19]$. Other responsible mechanisms may be related with calcium and piridoxin. There are reports showing that calcium-content reduces adiponectin, which may be explained that calcium reduces production of fatty acid and promotes lipolysis; whereas piridoxin may be modulating intracellular calcium signaling and lipid metabolism regulation [20].

Our findings contribute to the understanding of how diet composition and the time of specific diet consumption are able to induce higher adiponectin and the associated cardiometabolic benefits. However, some limitations of the study should be considered. First, the heterogenicity of the population regarding life styles, co-morbidities and drug therapies; while a healthy control group was not included. Second, the low sample size, which may be a source for potential bias. Third, the nutriments content in the diet was estimated through a 24-hour recall approach, whereas a direct measure of nutriments would be more accurate.

\section{Conclusion}

Results obtained from the present study suggest that diet content of non-saturated fatty acids decreases plasma adiponectin in patients with metabolic syndrome.

\section{Declarations}

\section{Ethical approval and consent to participate}

The study was designed and performed according to ethical guidelines of the 1975 Declaration of Helsinki, and it was approved by the Local Committees of Research, Ethics in Research and Biosafety of the Centro Médico Nacional '20 de Noviembre' ISSSTE, Mexico City. All participants provided written informed consent.

\section{Consent for publication}

The authors state that they have read and approve the present manuscript and give their consent for publication.

\section{Availability of data and materials}

The datasets used and/or analysed during the current study are available from the corresponding author on reasonable request.

\section{Competing interests}

The authors declare that they have no competing interests 


\section{Funding}

This project was supported by E-015 Program ISSSTE.

\section{Authors' contributions}

JAS-C, DED-J, JAP-J, were responsible for the conception, design and revision of the study and drafting the manuscript. AGM-M, ODV-A, SN-A, EV-G, AH-P, ME-T, PL-M, JAL-V, RP-CdeV, JRA-M, AAG-P, BB-F, JM-R, MAD-A, RCC-H, AM-L, SG, JG-S and PM-T were responsible for the generation, collection, analysis and interpretation of data.

\section{Acknowledgments}

The authors acknowledge the support from E-015 Program ISSSTE.

\section{References}

1. Saklayen MG. The Global Epidemic of the Metabolic Syndrome. Curr Hypertens Rep. 2018 Feb 26;20(2):12. doi: 10.1007/s11906-018-0812-z.

2. Grundy SM, Cleeman JI, Daniels SR, Donato KA, Eckel RH, Franklin BA, Gordon DJ, Krauss RM, Savage PJ, Smith SC Jr, Spertus JA, Costa F; American Heart Association; National Heart, Lung, and Blood Institute. Diagnosis and management of the metabolic syndrome: an American Heart Association/National Heart, Lung, and Blood Institute Scientific Statement. Circulation. 2005 Oct 25;112(17):2735-52. doi: 10.1161/CIRCULATIONAHA.105.169404.

3. O'Neill S, O'Driscoll L. Metabolic syndrome: a closer look at the growing epidemic and its associated pathologies. Obes Rev. 2015 Jan;16(1):1-12. doi: 10.1111/obr.12229.

4. Pal S, Ellis V. The chronic effects of whey proteins on blood pressure, vascular function, and inflammatory markers in overweight individuals. Obesity (Silver Spring). 2010 Jul;18(7):1354-9. doi: 10.1038/oby.2009.397.

5. Silva FM, de Almeida JC, Feoli AM. Effect of diet on adiponectin levels in blood. Nutr Rev. 2011 Oct;69(10):599-612. doi: 10.1111/j.1753-4887.2011.00414

6. Qi L, Rimm E, Liu S, Rifai N, Hu FB. Dietary glycemic index, glycemic load, cereal fiber, and plasma adiponectin concentration in diabetic men. Diabetes Care. 2005 May;28(5):1022-8. doi: 10.2337/diacare.28.5.1022.

7. Mantzoros CS, Williams CJ, Manson JE, Meigs JB, Hu FB. Adherence to the Mediterranean dietary pattern is positively associated with plasma adiponectin concentrations in diabetic women. Am J Clin Nutr. 2006 Aug;84(2):328-35. doi: 10.1093/ajcn/84.1.328.

8. Nakamura Y, Ueshima H, Okuda N, Higashiyama A, Kita Y, Kadowaki T, Okamura T, Murakami Y, Okayama A, Choudhury SR, Rodriguez B, Curb JD, Stamler J; INTERLIPID Research Group. Relation of dietary and other lifestyle traits to difference in serum adiponectin concentration of Japanese in 
Japan and Hawaii: the INTERLIPID Study. Am J Clin Nutr. 2008 Aug;88(2):424-30.

doi:10.1093/ajcn/88.2.424.

9. González Rodríguez DC, Solano R L, González Martínez JC. Adiponectina, insulina y glicemia, en individuos con sobrepeso u obesidad sometidos a un régimen de alimentación rico en carbohidratos complejos [Adiponectin, insulin and glucose concentrations in overweight and obese subjects after a complex carbohydrates (fiber) diet]. Arch Latinoam Nutr. 2009 Sep;59(3):296-303. Spanish.

10. Esposito K, Nappo F, Giugliano F, Di Palo C, Ciotola M, Barbieri M, Paolisso G, Giugliano D. Meal modulation of circulating interleukin 18 and adiponectin concentrations in healthy subjects and in patients with type 2 diabetes mellitus. Am J Clin Nutr. 2003 Dec;78(6):1135-40. doi:

10.1093/ajcn/78.6.1135.

11. Weiss EP, Racette SB, Villareal DT, Fontana L, Steger-May K, Schechtman KB, Klein S, Holloszy JO; Washington University School of Medicine CALERIE Group. Improvements in glucose tolerance and insulin action induced by increasing energy expenditure or decreasing energy intake: a randomized controlled trial. Am J Clin Nutr. 2006 Nov;84(5):1033-42. doi: 10.1093/ajcn/84.5.1033.

12. Garaulet M, Viguerie N, Porubsky S, Klimcakova E, Clement K, Langin D, Stich V. Adiponectin gene expression and plasma values in obese women during very-low-calorie diet. Relationship with cardiovascular risk factors and insulin resistance. J Clin Endocrinol Metab. 2004 Feb;89(2):756-60. doi: 10.1210/jc.2003-031495.

13. Xydakis AM, Case CC, Jones PH, Hoogeveen RC, Liu MY, Smith EO, Nelson KW, Ballantyne CM. Adiponectin, inflammation, and the expression of the metabolic syndrome in obese individuals: the impact of rapid weight loss through caloric restriction. J Clin Endocrinol Metab. 2004 Jun;89(6):2697-703. doi: 10.1210/jc.2003-031826.

14. Imbeault P, Pomerleau M, Harper ME, Doucet E. Unchanged fasting and postprandial adiponectin levels following a 4-day caloric restriction in young healthy men. Clin Endocrinol (Oxf). 2004 Apr;60(4):429-33. doi: 10.1111/j.1365-2265.2004.01997.x.

15. Aparicio, M., Estrada, L., Fernández, C., et al. Manual de Antropometría INNSZ. 2da. Edición. Saucedo, G., Villa, A., Aguilar, C., Chávez, A. (eds). México. 2004. pp:7,8.

16. Peake PW, Kriketos AD, Denyer GS, Campbell LV, Charlesworth JA. The postprandial response of adiponectin to a high-fat meal in normal and insulin-resistant subjects. Int $\mathrm{J}$ Obes Relat Metab Disord. 2003 Jun;27(6):657-62. doi: 10.1038/sj.ijo.0802289.

17. Paniagua JA, Gallego de la Sacristana A, Romero I, Vidal-Puig A, Latre JM, Sanchez E, Perez-Martinez P, Lopez-Miranda J, Perez-Jimenez F. Monounsaturated fat-rich diet prevents central body fat distribution and decreases postprandial adiponectin expression induced by a carbohydrate-rich diet in insulin-resistant subjects. Diabetes Care. 2007 Jul;30(7):1717-23. doi: 10.2337/dc06-2220

18. Flachs P, Mohamed-Ali V, Horakova O, Rossmeisl M, Hosseinzadeh-Attar MJ, Hensler M, Ruzickova J, Kopecky J. Polyunsaturated fatty acids of marine origin induce adiponectin in mice fed a high-fat diet. Diabetologia. 2006 Feb;49(2):394-7. doi: 10.1007/s00125-005-0053-y. 
19. Soares AF, Guichardant M, Cozzone D, Bernoud-Hubac N, Bouzaïdi-Tiali N, Lagarde M, Géloën A. Effects of oxidative stress on adiponectin secretion and lactate production in 3T3-L1 adipocytes. Free Radic Biol Med. 2005 Apr 1;38(7):882-9. doi: 10.1016/j.freeradbiomed.2004.12.010.

20. Zemel MB, Bruckbauer A. Effects of a leucine and pyridoxine-containing nutraceutical on fat oxidation, and oxidative and inflammatory stress in overweight and obese subjects. Nutrients. 2012 Jun;4(6):529-41. doi: 10.3390/nu4060529.

\section{Figures}

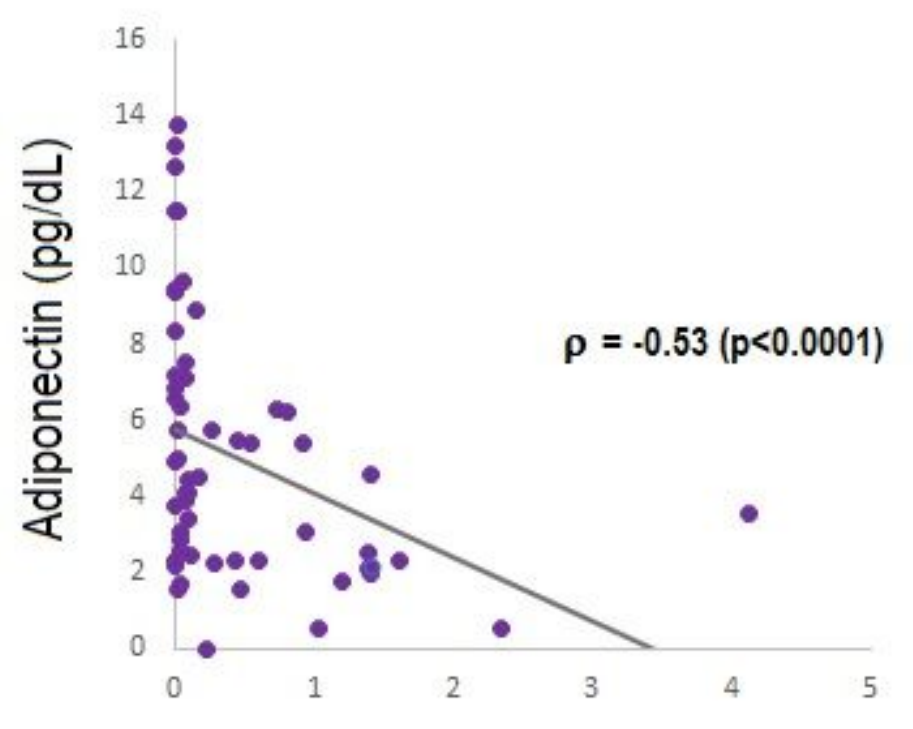

Trans fatty acids $(\mathrm{g})$

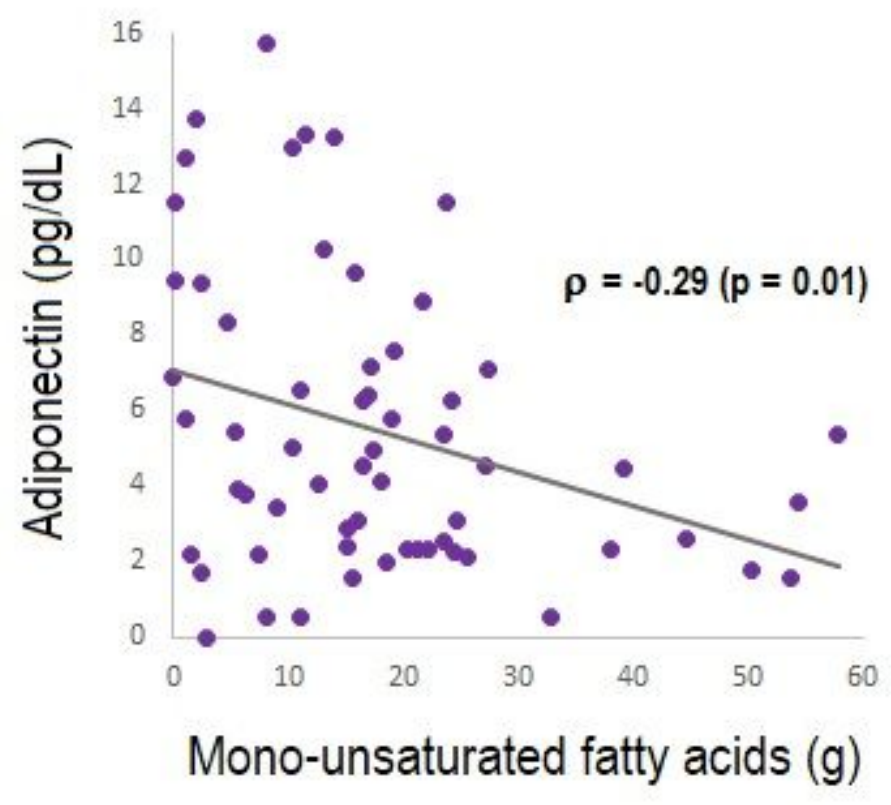

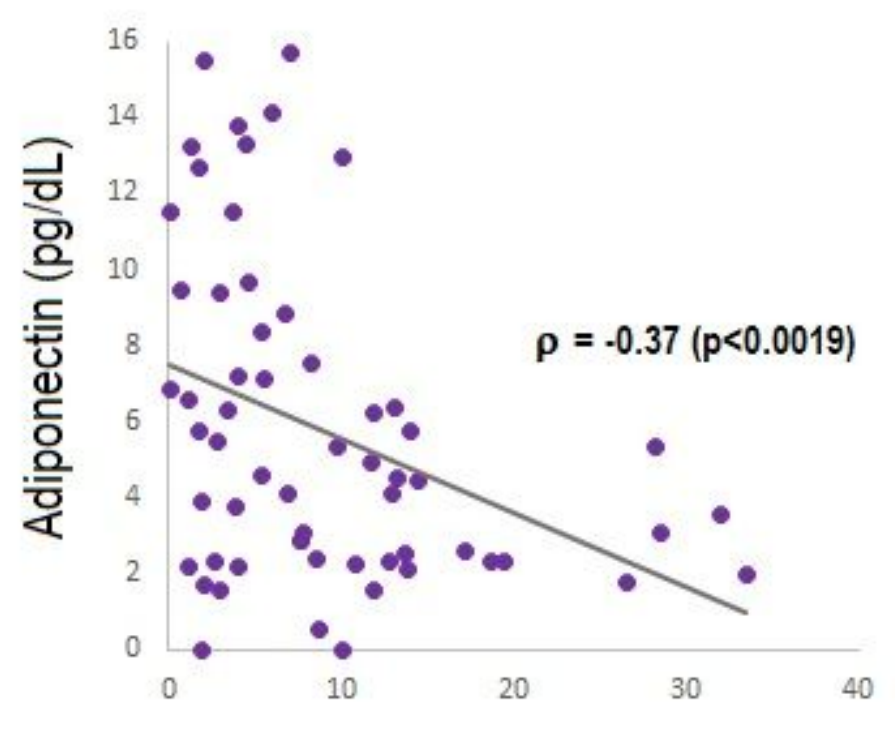

Poly-unsaturated fatty acids $(\mathrm{g})$

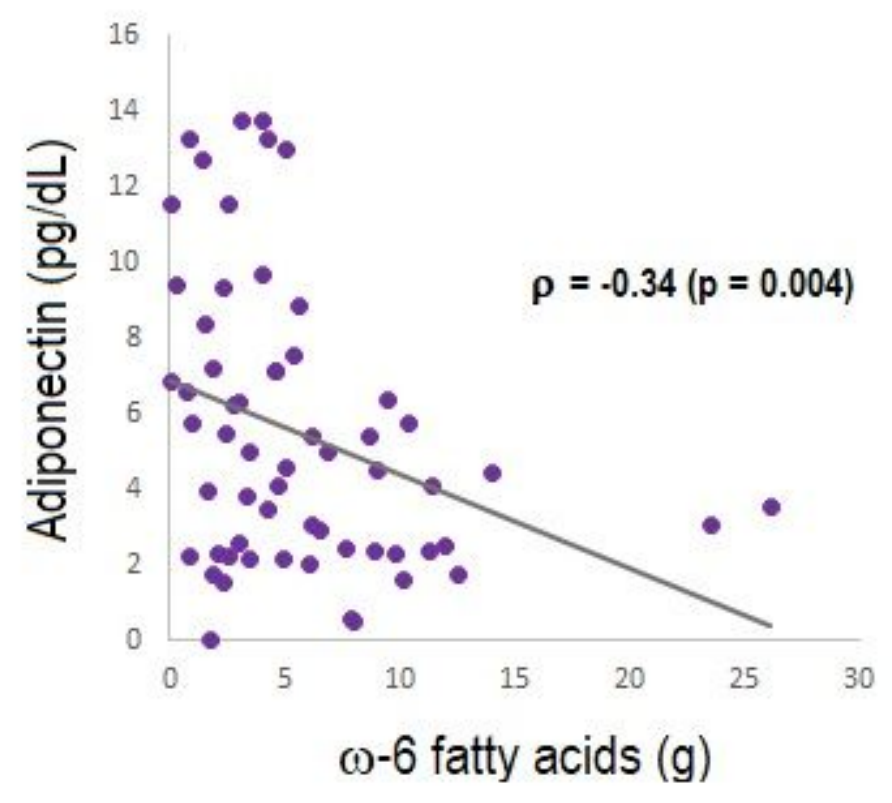

Figure 1 
Dietary components most related with plasma adiponectin. The figure shows the correlations between micronutrients most significantly related to plasma adiponectin. Spearman correlation. 